\title{
Mediating the global order: the past and future of Asia- Pacific regional organizations
}

\author{
Michael Wesley
}

Regionalism in the Asia-Pacific-a topic that has spawned a veritable cottage industry of definitions over the past decade--is at its weakest and most contested level since the end of the Cold War. Four years ago, a financial crisis occurred which had much more profound effects than just on regional economies. The Asian crisis deflated expectations of uninterrupted regional economic growth, the 21 st century as the 'Asian century', the Asian 'model' as the superior way of producing economic growth. The aftermath of the crisis challenged deeply-held norms of regional institutions and diplomacy: national and regional resilience; political and social stability; and sovereign independence and non-intervention. The crisis also had profound effects on regional institutions: the Asian Development Bank (ADB), Association of Southeast Asian Nations (ASEAN), Asia-Pacific Economic Cooperation organization (APEC), and the ASEAN Regional Forum (ARF). At best, the current regional order is based on a number of institutions that are inert or in danger of imminent demise, plus a number of partially articulated alternative schemes for regional order that are unevenly supported, and then often not for the same reasons. Overlaying this is a worsening situation of strategic competition-mostly over the nature of the regional order-between the United States and China.

If we follow Michael Antolik's distinction between regional organization, 'the commitment of several states to reach common goals by means of joint policy undertakings'; and regionalism, 'a belief that a commonality (if not a community) exists and should be fostered...regionalism assumes that affinities and shared grievances will promote cohesion' (Antolik 1990, 10), the conclusion is inescapable that the weakness and lack of direction of the region's political structures derives directly from the frailty (or extinction) of an ideational 
consensus on the nature and purposes of regional association. At the present time, Australia is not the only country beset by a deep ambivalence over how it relates to the region. A quick survey of the Asia-Pacific's countries shows a broader range of definitions of the regional order than perhaps at any time since the Second World War, with a corresponding variety of conceptions about how the region's states relate to the regional order.

In proposing a diagnosis for this situation, I would like to advance a new conceptual approach to regional organization; an approach which I argue is better equipped to make sense of the singular nature of regional organization in the AsiaPacific. My approach is to suggest that regionalism and regional organization in the Asia-Pacific have always played a mediating role between the particularist interests of the region's states and the US-defined global order. Regional structures have been developed to allow Asia-Pacific states to retain the beneficial aspects of global order while filtering out or alleviating the damaging or intrusive aspects. As both global order and particular state interests change, new demands are made of the mediation role, and regional organizations are altered to meet these demands. This approach suggests a new explanation for the current malaise of regional organizations: the combination of a new, undefined, and unstable global order; plus a chronic lack of agreement by regional countries about what is benign and what is malign about that global order. Unfortunately, this explanation implies a poor prognosis for regional institutions over the next ten years.

There are four parts to my argument. I begin by developing and explaining my approach to regional organizations. I then apply this to the regional organizations of the Asia-Pacific chronologically, documenting the mediating role of regionalism in three successive periods: during the Cold War, in the post-Cold War era (1989-97), and in the post-Crisis era (taking in the current and future state of regional organizations).

\section{Regionalism as mediation}

At the risk of chronic over-simplification, there have been broadly four approaches to explaining the rise of regional organizations since the Second World War. The first are 'peace-based' approaches, variants of functionalist theory that suggest that regional integration has been adopted to overcome chronic insecurity and rivalry between neighbouring states (Mitrany 1933; Mitrany 1966; Haas 1958; Monnet 1976; Nye 1971). The second are 'power based' approaches that suggest regionalism is the result of competition between political units in an international system where the size of populations, territories, production runs, and markets are the attributes of power (Delors 1992; Kennedy 1993; Cox 1992; Thurow 1993). The third are 'cultural-identity' approaches, suggesting regionalism arises from existing or emerging continuities in values (Deutsch 1957; Hurrell 1995; Adler and Barnett 1998). The fourth are 'economics-derived' approaches, which argue that regionalism is a response to various economic dilemmas and forces, from the resurgence of mercantilism and the crisis of the global trading regime to the need 
to respond to the forces of economic globalization (Gilpin 1987; Moravcsik 1998). Yet none of these approaches can explain why regional organizations arose and prokiferated when they did: the first three would suggest that regionalism should have been developed long before the post-War period; the fourth cannot explain why regional organizations developed long before the modern age of globalization. None of them have been able to offer much purchase on explaining regionalism in the Asia-Pacific.

I would argue that regionalism, as a process that has developed since the Second World War, is primarily a mediating response to the two defining processes of that period: the construction for the first time of a truly global interstate order-as opposed to previous regional systems linked to the rest of the world through colonial and racially-hierarchic ties-and the widespread adoption of the state form by the decolonizing world. The construction of a global order was driven by a universalist conception of politics: a belief that all political structures were expressions of the same basic constituents and principles and therefore inherently comparable. On the other hand the form of the sovereign state, which implied mutual exclusivity of authority, and the ideology of national selfdetermination demanding that each 'people' be able to rule itself as it saw fit, rested on the opposite concept of particularism. In an Hegelian manner, this universalist conception of global politics implied its opposite-particularist sovereignty - -while the system of state particularities implied their opposite: a universalist system of partitioned sovereignties.

A universalist approach was required for the conception and then construction of a world order. The United States needed general principles of conduct and order as a guide for gauging the impact of diverse developments in world politics on its global interests; but these general principles were at the same time deeply particularist in their ethnocentrism. American universalism springs from a range of attributes: an Enlightenment culture and Lockean understanding of politics (Hoffmann 1977); an experience of and approach to colonialism that stressed access and an 'open door' to other territories rather than exclusive control (Huntington 1973); and the reliance of an immigrant nation on a general set of principles of political association superior to cultural or linguistic particularities (Ruggie 1996, 25-6). It was the United States that insisted-after both the First and the Second World Wars - on the dismantling of empires and the adoption of the state form on the basis of national self-determination as the ordering form of international relations. While national self-determination relied on the particularist conception of 'peoples' as organic specificities, the state form was itself a universal political form, and recognition of statehood required the achievement of several general principles of political control over territory and population.

For most decolonizing states, gaining sovereign statehood was an achievement of the utmost value, a political commodity of supreme importance. Yet their adoption of a particularist political structure occurred at a time in world politics flooded with universalist doctrines - the general principles of conduct embodied in 
the United Nations charter and the Bretton Woods institutions; liberal democracy, free market capitalism, communism, modernization-development-all structured the choices to be taken within each particularist sovereignty. Cold War rivalry drove the universalism of both east and west in ever more intrusive forms, ranging from the structure and conditionality of aid and development programs to the waging of proxy wars in the recently decolonized world. To different extents, the regional organizations that developed since the early 1950s in Europe, Latin America, Africa, and Southeast Asia emerged as strategies to manage the conflict between the utmost value of particularism and the demands of universalism. Regionalism developed as a mediation strategy, to preserve as much sovereignty and independence as possible for small states, while allowing them to partake of the beneficial aspects of universalism and filter out the harmful and intrusive aspects. The mediation role was of varying success in different regions. In the Asia-Pacific, it was employed relatively more effectively than in other regions, and regionalism was retained and modified over time as the demands of universalism and particularism changed.

\section{Asia-Pacific regionalism during the Cold War}

The world order that was constructed after the Second World War was intended to apply universally, but was soon modified and confined by Cold War competition. The universalist principles that had originally been designed from the time of the Atlantic Charter in 1942 to provide a solid foundation for peace and development were soon redirected towards bolstering the free world in the struggle against communism. The first such principles to morph were anti-colonialism and modernizing development, which from the time of the Truman Doctrine were reoriented towards anti-communism. By the 1950 s, a United States which had been dedicated to the dismantling of colonial empires was providing support to the French as they tried to re-assert their imperial control over Indochina. Repeatedly in the Asia-Pacific, communism and anti-communism assumed interventionist forms. While most new states in the region defined themselves as either communist or non-communist, all retained a strong desire to retain their sovereignty and particularism in the face of the universalist drives of the superpowers. In security terms, the challenge was to reconcile a commitment to pro or anti-communism with the preservation of sovereign independence.

World order universalism manifested itself in economic terms in a number of ways. Most basically, American globalism was based on a concept of development as modernization, the belief that political independence would be followed by a process of development along the path already trodden by the industrialized democracies (Packenham 1973). As a motivator of global development policies-through bilateral US aid as well as the multilateral development banks - - this concept of development sat comfortably with the Cold War doctrine that economic strength and modernization provided a solid bulwark against communist subversion and expansion (Rostow 1960). In addition to this, as John 
Ruggie argues, economic universalism was based on the 'embedded liberalism compromise', an attempt to marry a commitment to free trade and stable currency exchange with domestic economic policies dedicated to Keynesian principles of interventionism, planning, and stable economic growth (Ruggie 1998, 72-4).

The third univeralist principle of the American world order was that of multilateralism. Initially conceived in global terms and with universal membership -as demonstrated by the first postwar multilateralist institutions construeted at San Fransisco and Bretton Woods-multilateralism was a political structure intended to manage various aspects of international relations according to rational and consensual principles. Basic to the American form of multilateralism-and deeply at odds with the European great power multilateralism of the Concert of Europe-was a democratic conception that political institutions could only be based on a foundational constitutional act participated in by all who were subject to it at the point of formation. As with domestic institutions, international institutions were not open to renegotiation by decolonized states that had been colonies at the time of their founding; post-1945 members of the UN, IMF, and World Bank were required to accept their negotiated structure in full. American multilateralism also rested on a conception of international relations as the interplay of calculations of self-interest; cooperation was only possible as an exchange of obligations that was voluntary and based on a strict conception of interest-based reciprocity. Ruggie has observed that the multilateral form was deeply universalist:

[M]ultilateralism is an institutional form that coordinates relations among three or more states on the basis of generalized principles of conduct: that is, principles which specify appropriate conduct for a class of actions, without regard to the particularistic interests of the parties or the strategic exigencies that may exist in any specific occurrence (Ruggie 1993, 11).

Coinciding with these universalist doctrines of world order was the spread of the state form according to the concept of national self-determination to the decolonizing world. Ironically, the experience of particularism and mutual territorial exclusivity had been introduced by the colonial experience itself, as the European powers had constructed clear lines of demarcation between their colonies. The post-colonial reaction was naturally one that prized independence and self-rule above all other values; while the experience of international juridical equality was a refreshing change after the experience of the racially hierarchical colonial world order. Even as they acceded to the United Nations and other institutions of global order, post-colonial states placed great store on the state as a self-contained moral and material proprietor, responsible only to itself for the conduct of its affairs.

In security terms, the primary task was to suppress internal subversion and forestall international intervention. Economically, the priority was national selfdevelopment, strongly conditioned by an awareness of post-colonial dependence 
on commodities trade and the experience of external determination of economic structures. The response was most often the adoption of some variant of autarkic, import-replacing self-development policy, strongly influenced by the prevailing aid doctrines of the $1950 \mathrm{~s}$ and $1960 \mathrm{~s}$ that prioritized the achievement of selfsufficiency in agriculture production. In their external relations, the post-colonial states of the Asia-Pacific adopted a statecraft responsive to the dictates of exigency and security, extremely protective of their sovereign prerogatives and independence, and deeply suspicious and rivalrous with neighbouring states.

The universalist principles of the post-Second World War global order had provided post-colonial Asia-Pacific states with their cherished particularist right to self-determination, yet at the same time the hyper-universalism of the Cold War threatened to compromise this new-found independence. For the post-colonial world, the search for mediating mechanisms was urgent. The very independence they had gained left them highly vulnerable to superpower intervention or cooption. The first response of the post-colonial world was to buy out of the central balance at Bandung in 1955; and the discovery of solidarity in non-alignment-and later in developmentalism in the Group of 77 -had a profound influence on the Asia-Pacific. In the first place, it ensured the stillbirth of the extension of the US multilateral alliance system into the Asia-Pacific, ensuring that the South East Asia Treaty Organization (SEATO) had too many holes to be a serious piece of regional architecture.

The experiment in non-alignment informed an alternative regionalism in Southeast Asia, one inspired by a belief in the benefits of a solidarity dedicated to independence. By the time ASEAN formed in 1967, after experiments with the Association of Southeast Asia (ASA) and the three-nation 'Maphilindo' agreement, it had adopted a distinctive formula designed to use regionalism as a mediation strategy between Cold War universalism and the demands of particularist sovereignty. The formula that the non-Communist states of Southeast Asia committed to was to adopt regional resilience as an extension of - and always subordinate to-national resilience. In security terms, regional resilience meant the resolution, or at least suppression, of damaging suspicion and conflict between regional states in a way that might draw in external intervention. Economically, the urge to autarky and self-development was also extended from the national to the regional levels with the experiment with the ASEAN Industrial Joint Ventures in the late 1970s.

Originally ASEAN was dedicated to ensuring the minimum conditions needed to forestall intervention in Southeast Asia, guaranteeing basic anti-communism, inter-mural normalization of relations, and regional stability as a way of protecting each member's independence. Beneath this common commitment lay a range of differences, in political, economic, social, and cultural structures, in attitudes to alliance and non-alignment; and a high level of continuing mutual suspicion and rivalry. Regionalism in the Asia-Pacific adopted the multilateral form, but in a distinctive way. The only generalized principle consistently adhered to and 
eventually enshrined in the 'ASEAN way' was that of the supremacy of the principles of sovereignty and non-intervention. For the ASEAN five, a weak regional organization with low capacity to innovate and low expectations of compliance was a small price to pay to safeguard their particularist sovereignty. In fact, the elevation of sovereignty and non-intervention to a multilateral principle of regional organization was a crucial mediation mechanism, adapting the pressures of the universalist Cold War world order to be more compatible with their particularism. This formula allowed the retention of the US presence in Southeast Asia - with all of the benefits of regional stability, the deterrence of communist expansion, and the flow of economic aid-while keeping that presence as noninterventionist as possible.

\section{Asia-Pacific regionalism in the post-Cold War period, 1989-97}

The end of the Cold War changed both the universalist conception of the global order and saw an evolution in the particularist interests of Asia-Pacific states. Correspondingly, we can observe a profound change in regional institutions, as new demands on the mediation capacity of regionalism were set up by these changes at the universal and particularist levels. Once again, the form and design of these institutional departures is best able to be understood if first we investigate how changes at the global and particularist levels generated new demands on regional mediation.

The new universalism after the Cold War was driven by two separate perceptions in the United States: that alternatives to liberal democracy had been vanquished; and that there now should be nothing to stop the global adoption of liberal democracy, or the accession of all national economies to the global market. A number of factors combined to make the new universalism more challenging to particularism than even Cold War universalism. In many ways, American universalism assumed an even more messianic homogenizing urge. The new world order was a chance to forge world politics anew. Most fundamentally for AsiaPacific states, adherence to basic non-communism (or an anti-Soviet posture) was removed as a way of deflecting attention from domestic political, social, and economic organization. The 'enlargement' doctrine of the Clinton administration drew on theories of peaceful relations among democracies to argue a direct security interest in the promotion of liberal democracy in other states. As neoliberal economic theory gained intellectual ascendancy, the 'embedded liberalism' compromise was abandoned in favour of strong advocacy of free market principles, while the ideology of globalization and the discipline of the market was used to warn against variations in states' macroeconomic policies.

Coinciding with the new universalism was a new particularism in the AsiaPacific. Concern over subversion and commitment to economic autarky were no longer preoccupations by 1989 , with strong evidence that the Asian economic miracle was extending beyond Japan. The new particularist concern was to ensure that nothing disrupt the conditions for economic growth. Overlaying this 
instrumentalist urge was a new normative belief that Asia had found a superior way of delivering economic development and social cohesion. Both of these convictions were used to defend soft authoritarianism and greater state involvement in the economy, on the argument that the unprecedented rates of economic growth vindicated the unique political and social organization of certain Asia-Pacific states. Arguments emerged asserting the existence of distinctive 'Asian values', marrying beliefs in potency and particularism, as a reaction to the homogenizing stridency of world order universalism. In security terms, rising prosperity drove the resurgence of intra-mural rivalries and spurred localized arms racing and a revisiting of territorial conflicts.

The period between 1989 and 1994 remains the most frenetic period of building and innovation in the history of Asia-Pacific regionalism. The catalogue itself rivals the post-Cold War institutional innovation of any region in the world: the creation of APEC in 1989; the Singapore Summit developments and the announcement of the ASEAN Free Trade Area in 1992; the APEC Leaders Summits in 1993; the inauguration of the ASEAN Regional Forum in 1994. Taken together, all of these innovations constitute strong evidence of an urgent need for regional mediation between the new global universalism and particularist urges in the Asia-Pacific. The booming Asia-Pacific economies needed to maintain the benefits of the US security presence in the region, and retain access to the US market and global investment flows to fuel their export-oriented development. However, the danger was that a newly messianic United States, freed of Cold War concerns about driving states into the arms of the communist bloc, would use these benefits as bargaining chips to force American-style political and economic homogenization on regional states.

The solution adopted was a variation on the earlier theme of using regionalism to ensure basic compatibility with the minimum conditions required to accommodate the benign aspects of world order, while keeping its more interventionist aspects at bay. The major departure was the willingness of regional states to include the US in regional bodies as a way of 'tying in' the US presence in the region, but trying to dilute US influence through the diffuse and highly consensual mechanisms of the new regional organizations. The slow development of APEC between 1989 and 1994, and the creation of the ASEAN Free Trade Area at the Singapore ASEAN Leaders Summit in January 1992 were initially a response to globalization, and the fear that the accession of former communist and developing economies to the global market would draw away investment from the Asia-Pacific. The response was to send a strong signal to global markets about the attractiveness of the region as a site for investment. Asia-Pacific regionalism was prepared to go that far to accede to universalist principles; but neither AFTA nor APEC even contemplated surrendering the supreme values of sovereignty and independence to the new world order. Instead, ASEAN-style consensualism was built into both organizations as a way of keeping the further demands of the 
universalist world order at bay. The ASEAN Regional Forum emerged and engaged similar principles in 1994.

The other major departure was the development of what I call 'completion regionalism', the urge to define and complete Asia-Pacific regionalism by absorbing into old and new regional structures those states that had been excluded during the Cold War. The expansion of memberships gave the new Asia-Pacific organizations added weight, as well as harnessing the reputation of the Asian economic miracle as a defining principle of regional association. Completion regionalism became an additional strand in the mediation of the global order, particularly as the insistence on non-intervention from communist states was used to buttress the regional non-intervention norms of the smaller, soft authoritarian states. Finally, at Bangkok in April 1993, the particularist rhetoric of Asian values was regionalized through the Bangkok Declaration on human rights, stressing that universalist human rights values should not be imposed from outside but be attentive to cultural variations.

\section{Post-Asian crisis regionalism}

The 1990s saw a series of developments heralding a period of greater US capacity and willingness to intervene, coupled with a deepening uncertainty over the desirable nature of world order. The US economy registered its longest period of uninterrupted economic growth coupled with low unemployment and low inflation since the 1960s. This, coupled with the repeated demonstration of American military prowess and lead in military technology in the Gulf War and the Balkans put an end both to the declinist theses of the late 1980 s and post-Vietnam selfdoubt. Additionally, the most likely mechanisms of Clinton's new world order-the UN and regional organizations particularly in Europe--had proved deeply ineffective over a range of situations from Somalia to the Balkans. As the United States was relied on to salvage a range of crises, a new realism began to sink in about the possibilities of a new world order.

In the Asia-Pacific, evidence began to mount early in the second Clinton administration that US impatience with post-Cold War institutions included those in the Asia-Pacific. As the concerted unilateral approach to trade liberalization in APEC began to stall, the United States began to agitate for a departure in early voluntary sectoral liberalization. And as the ARF's attempts to define preventive diplomacy turned into a comprehensive block to further progress in that institution, the United States moved to renegotiate its defence guidelines with Japan.

Most disturbing for Asia-Pacific states was US behaviour during and after the Asian financial crisis. Repeated statements by US policy-makers emphasized that the crisis was first and foremost an opportunity to reorganize economic, political, and social structures in the region's states. For many, this constituted evidence of a new, more muscular, interventionism on economic governance that parallelled the military human rights interventionism over Kosovo. For most, what was most worrying was an apparent willingness to invert American world order priorities. 
Hitherto, the United States had paid most attention to outcomes in world politics, being largely willing to forgive political, social and economic structures as long as they were consistent with producing desirable results: non-communism, stability, economic growth. With the Asian crisis, these priorities seemed to have been inverted as the United States seemed prepared to accept regional instability and economic crisis in the interests of promoting what it considered to be more appropriate political and economic structures.

Corresponding to these unsettling developments in the principles of world order has been a fracturing of particularist conceptions among Asia-Pacific states. Previously, Asia-Pacific states had shared broad agreement on the need to protect their sovereignty and independence, from each other as much as from the interventionist impulses of the global order. A number of processes have combined to produce this range of particularist conceptions. The first has been the partial advance of democratization through the region, to South Korea, Taiwan, Thailand, the Philippines, and latterly to Indonesia. The second is the relatively faster development of the former Asian 'tigers'; the third the development of middle classes and civil society groups with moderate international linkages. These developments have eroded basic similarities of outlook not only between the new democracies and the continuing soft authoritarian states; but also between the 'original ASEANs' and the newer members in Indochina and Myanmar; and between the more vigorous trading economies and the more traditional commodity producers. Interpretations of the Asian crisis also reveal deep divisions between those who see its causes in structural problems and ill-chosen policy settings domestically, and those who diagnose its causes at the level of the global financial system.

Between an uncertain universalism and fractured particularism, Asia-Pacific regional institutions have entered a period of deep torpor and crisis. Even before the onset of the Asian crisis, inclusive regionalism was under challenge. Against strong criticism from the US and the EU, ASEAN insisted on admitting Myanmar to membership on the principles of non-interference and 'constructive engagement' in 1997. It was these principles that Cambodia used to criticise ASEAN's decision to defer its accession to ASEAN membership after the Hun Sen coup, also in 1997. As further internal problems dogged Myanmar and Cambodia, ASEAN issued statements calling for stability and reform in Myanmar and Cambodia; but in giving credence to its 'constructive engagement' justifications for admitting these members, it had begun to abandon its non-intervention principles.

After the Asian crisis, further fractures began to develop in regional structures. A major division occurred in ASEAN between a reformist coalition of the democracies (Thailand and the Philippines) plus the more developed members (Singapore), which advocated a limited repeal of non-interventionist principles, and the newer members which insisted on the value of 'solidarity' in the face of all of the challenges of the crisis. The latter were victorious at the Hanoi Summit in December 1998 , but at the cost of seriously eroding the commitment to ASEAN of 
its more dynamic members. The second division occurred over specific reactions to the crisis, between those demanding greater regional autonomy and those placing their trust in global solutions. Many believed that global structures had failed the region (and were even partly culpable for the depth of the crisis) and that a regional mechanism in the shape of an Asian Monetary Fund was necessary for future recurrences. They were opposed by those who insisted at the November 1997 APEC Leaders Meeting that global structures were the most appropriate response. Once again, the conservative response prevailed, again at the price of undermining commitment to regionalism.

\section{Conclusion}

While these conditions of instability and division exist at the global order and state particularist levels, the prognosis remains unpromising for regional organizations in the Asia-Pacific. The major problem is that there exists a range of different levels of attachment to the global order by regional states. At one end of the spectrum there are those states such as Singapore and Thailand, which have, if not a deep affective attachment to the world order, at least have strong instrumentalist attachment to it, believing that the principles of world order are conducive to the needs and interests of the state. Further along, there are states such as South Korea which exhibit a pragmatic acceptance of the global order, believing that existing structures and power configurations have to be worked with in the interests of the state.

At the opposite end of the spectrum are those such as Malaysia and China and some policy-makers in Japan that are to varying extents opposed to the global order, seeing it as an expression of US power and believing it to frustrate the state's needs and interests. Such states have formulated partial schemes for regional order that range from the revival of the Malaysian concept of the East Asian Economic Caucus in the ASEAN +3 arrangement, to the Japanese interest in financial regionalism in the shape of the Asian Monetary Fund. The interesting thing about these schemes is that they are a departure from previous regional mediation mechanisms, in being not so much a filter for world order principles as partial alternatives on a regional scale. Yet they remain partially formed, being much more attuned to the particularist interests of regional states than to articulating alternative general principles to those of the universalist world order.

Thus one of the greatest uncertainties about the next decade in the Asia-Pacific concerns the health of its regional organizations. What seems to be required is a new vision about the purpose of regionalism, identifying commonalities in aspirations and aversions, as a prerequisite for revitalizing the regional organizations themselves. Such a vision will, as before, need to relate both to the contemporary principles of world order (when these are defined) and the particularist interests of the region's states. Yet while the possible sources of such a compelling vision-Japan, China, Indonesia-remain intensely focused on their own particularist policy concerns, the emergence of such a vision seems unlikely. 


\section{References}

Adlex, Emanuel, and Michael Barnett (eds). 1998. Security Communities. Cambridge: Cambridge University Press.

Antolik, Michael. 1990. ASEAN and the Diplomacy of Accommodation. Armonk: ME Sharpe.

Cox, Robert. 1992. 'Multilateralism and World Order', Review of International Studies, 18.

Delors, Jacques. 1992. Our Europe. London: Verso.

Deutsch, Karl W. et al. 1957. Political Community and the North Atlantic Area. Princeton: Princeton University Press.

Gilpin, Robert. 1987. The Political Economy of International Relations. Princeton: Princeton University Press.

Haas, Ernst. 1958. The Uniting of Europe. Stanford: Stanford University Press.

Hoffmann, Stanley. 1977. 'An American Social Science: International Relations', Daedalus. 106, pp. 41-60.

Huntington, Samuel P. 1973. 'Transnational Organizations and World Politics', World Politics. 25:3, April.

Hurrell, Andrew. 1995. 'Explaining the Resurgence of Regionalism in World Politics', Review of International Studies. 21.

Kennedy, Paul. 1993. Preparing for the Twenty-First Century. London: HarperCollins.

Mitrany, David. 1933. The Progress of International Government. London; George Allen and Unwin.

Mitrany, David. 1966. A Working Peace System. Chicago: Quadrangle Books.

Monnet, Jean. 1976. Memoirs. Paris: Fayard.

Moravesik, Andrew. 1998. The Choice for Europe: Social Purpose and State Power from Messina to Maastricht. London: UCL Press.

Nye Jr., Joseph. 1971. Peace in Parts. Boston: Little, Brown and Co.

Packenham, Robert A. 1973. Liberal America and the Third World. Princeton: Princeton. University Press.

Rostow, W. W. 1960. The Stages of Economic Growth : A Non-Communist Manifesto. Cambridge: Cambridge University Press.

Ruggie, John Gerard. 1993. Multilateralism Matters: The Theory and Praxis of an Institutional Form. New York: Columbia University Press.

Ruggie, John Gerard. 1996. Winning the Peace: America and World Order in the New Era. New York: Columbia University Press.

Ruggie, John Gerard. 1998. Constructing the World Polity. London: Routledge.

Thurow, Lester. 1993. Head to Head. Sydney: Allen and Unwin. 